\title{
PENGOLAHAN LIMBAH KACA MENJADI PRODUK SENI KALIGRAFI GAMPONG JALIN KOTA JANTHO
}

\author{
Hatmi Negria Taruan ${ }^{1}$, Reza Sastra Wijaya ${ }^{2}$, Yulfa Haris Saputra ${ }^{3}$ \\ Program Studi Seni Rupa Murni \\ Institut Seni Budaya Indonesia Aceh \\ e-mail : hatmi.negria87@gmail.com, reyzasastra@gmail.com
}

Diterima : 1 Juli 2019. Disetujui : 30 Agustus 2019. Dipublikasikan : 27 Desember 2019

(c) (7) $\begin{aligned} & \text { (7) } 2019 \text { - DESKOVI Universitas Maarif Hasyim Latif. Ini adalah artikel dengan akses } \\ & \text { terbuka di bawah lisensi CC BY } 4.0 \text { (https://creativecommons.org/licenses/by/4.0/) }\end{aligned}$

\begin{abstract}
ABSTRAK
Limbah sering dikenal dengan sampah yang merupakan suatu bahan buangan hasil proses produksi industry dan rumah tangga dimana kehadirannya tidak diinginkan. Salah satu limbah yang adalah limbah kaca. Limbah kaca banyak terdapat ditemukan di tempat-tempat industri kaca seperti akuarium, pabrik botol minuman, pengolahan lemari kaca dan lain sebagainya. Desa jalin adalah salah satu kawasan di kota jantho aceh besar yang memiliki potensi kunjungan wisata alam yang ramah bagi seluruh kalangan. Oleh karena itu alangkah baiknya Kawasan ini dapat sekaligus dijadikan sebagai tempat pengolahan benda seni sebagai penambah daya tarik, salah satunya pengolahan limbah kaca. limbah kaca tersebut diolah dan dimanfaatkan agar menjadi suatu barang yang bernilai ekonomis. Salah satu cara mengolah limbah kaca menjadi produk seni kaligrafi yang bernilai ekonomis bagi masyarakat di kota jalin Jantho, Aceh Besar. Langkah dalam melakukan pengabdian masyarakat ini terdiri dari dua tahap, tahap pertama identifikasi masalah dan tahap kedua penyusunan program. Dalam penyusunan program terdiri dari beberapa tahapan antara lain : Persiapan kepada masyarakat, Pengenalan souvenir-souvenir yang menghasilkan produk yang kita inginkan dan cara pembuatannya, Mengajarkan kepada masyarakat cara mengolah bahan dan membuat produk di kampung Jalin.
\end{abstract}

Kata kunci: Limbah kaca, karya seni, kaligrafi, jalin

\begin{abstract}
Cesspit is often known as rubbish which is a cesspit material produced by industrial and home industry production processes where its presence is undesirable. One cesspit that is glass cesspit. Glass cesspit is found in many places in the glass industry such as aquariums, beverage bottle factories, glass cabinet processing and so on. The jalin vilage is one of the regions in the Aceh Besar jantho city that has the potential for friendly natural tourist visits for all walks of life. Therefore it would be nice this area can also be used as a place of processing of art objects as an addition to attraction, one of which is the treatment of glass cesspit. The glass cesspit is processed and utilized to become an economically valuable item. One way to process glass cesspit into calligraphy art products that are of economic value to people in the intertwined city of Jantho, Aceh Besar. This step in conducting community service consists of two stages, the first stage is the identification of problems and the second stage is the preparation of the program. In the preparation of the program consists of several stages, among others: Preparation to the community, introduction of souvenirs that produce the products we want and how to make them, teach the community how to process ingredients and make products in the village of Jalin
\end{abstract}

Keyword: Glass waste, artwork, calligraphy, Jalin

\section{PENDAHULUAN}

Limbah yang sering kita kenal dengan sampah merupakan suatu bahan buangan yang diproses dari hasil produksi industri dan rumah tangga dimana kehadirannya tidak dikehendaki. Hal ini dikarenakan menurunkan kualitas lingkungan dan tidak memiliki nilai ekonomi. Dengan kata lain, limbah merupakan sumber pencemaran lingkungan. Limbah terbagi dua, limbah cair dan limbah padat. Limbah padat inilah dikatakan sebagai sampah. Sampah sendiri terdiri dari sampah organik dan anorganik. Sampah organik merupakan sampah rumah tangga yang terdiri dari sampah nasi, sayuran, buah-buahan yang terkategorikan sampah yang mudah membusuk dan terurai. Sementara sampah anorganik terdiri dari sampah plastik, kaca, kertas dan lain-lain yang mana tidak dapat terurai dalam waktu singkat.

Kaca merupakan bahan yang tergolong pada material anorganik yang dihasilkan dari proses peleburan beberapa bahan dasar, kemudian bahan dasar hasil peleburan dilakukan proses pemadatan dengan 
proses pendinginan. Bahan dasar dari kaca adalah silica yang dilakukan peleburan pada suhu 1400 C. Kaca merupakan mineral padat yang bening (transparan) dan rapuh. Limbah kaca biasnaya ditemukan ditempattempat industri dimana kaca merupakan bahan utamanya seperti toko akuarium, pabrik botol minumaan, pembuatan kaca pintu/jendela dan pembuatan furniture. Biasanya limbah kaca yang dihasilkan dibuang ketempat sampah dan tidak diolah kembali. Apabila limbah kaca dibuang secara sembarangan akan berdampak negatif terutama pada lingkungan, dimana limbah kaca tersebut tidak dapat diuraikan secara biologis oleh tanah.

Sebagian besar masyarakat belum menyadari bahaya dari limbah kaca tersebut. Sekilas memang tampak tidak berbahaya, akan tetapi kaca merupakan material yang lebih berbahaya dari plastik karena tidak dapat hancur dengan sendirinya melainkan dengan pengolahan dengan metode tertentu. Pada dasarnya pengelolaannya limbah kaca akan menimbulkan dampak positif karena dapat diolah kembali menjadi suatu produk yang bernilai ekonomis serta memiliki kualitas yang baik.

Jalin merupakan salah satu kawasan perkampungan di kota jantho aceh besar yang memiliki potensi alam menguntungkan bagi masyarakat setempat. Kawasan jalin yang memiliki sumber daya alam yang asri dan belum termanfaatkan secara maksimal. Masyarakat jalin yang masih minim pengetahuan dalam membaca potensi ekonomis dalam pengelolaan sampah yang menimbulkan inisiatif untuk membentuk program pengabdian masyarakat kemitraan digampong jalin kota jantho Aceh Besar. Sasaran utama dari program pengabdian masyarakat ini adalah ibu-ibu rumah tangga yang berada didesa jalin kota jantho sehingga Ibu-ibu rumah tangga tersebut mempunyai penghasilan tambahan untuk meningkatkan perekonomian keluarga. Tujuan dari pengabdian masyarakat kemitraan melalui pengolahan dan pemanfaatan limbah kaca menjadi suatu karya seni kaligrafi ini adalah untuk menciptakan sebuah kerajinan baru di daerah aceh besar yang berpotensi menciptakan lapangan pekerjaan, menciptakan karakteristik kerajinan di bidang seni rupa yang mengemukakan nilai-nilai keislaman, dan meningkatkan perekonomian dan menjadikan kampung jalin sebagai sasaran tempat wisata kerajinan.

\section{METODE PENELITIAN}

Masyarakat kampung Jalin sebagian mayoritasnya tidak memiliki aktifitas selain Bertani. Hal inilah yang memunculkan ide untuk memberikan pelatihan pada warga untuk dapat beraktifitas yang memiliki nilai ekonomis bagi masyarakat setempat. Kegiatan ini juga ditujukan untuk melatih masyarakat dalam mengolah sumber daya alam yang ada sehingga memiliki nilai jual. Hal tersebut merupakan identifikasi masalah yang sekaligus merupakan ide awal pengabdian.
Untuk perealisasian kegiatan dilakukan beberapa tahapan yakni proses persiapan yang meliputi proses pengumpulan bahan dan alat, sosialisasi terhadap warga setempat, memperkenalkan aneka bentuk souvenir dari bahan-bahan bekas. Hal tersebut bermanfaat sebagai penarik minat masyarakat untuk mengikuti kegiatan pengabdian masyarakat berupa pelatihan pengolahan limbah kaca. Selanjutnya dilakukan tahapan inti dari kegiatan yakni pelatihan masyarakat yang dilakukan langsung di gampong jalin yang berlokasi di depan halaman masjid desa tersebut. Pada tahap ini tim dan pembimbing memberikan pengetahuan seputar manejemen tentang organisasi masyarakat agar masyarakat mampu mengelolanya dengan benar untuk dapat dilanjutkanya menjadi usaha mandiri.

\section{PEMBAHASAN}

Limbah dapat diartikan sebagai benda buangan atau material sisa yang dianggap tidak memiliki nilai yang dihasilkan dari suatu proses produksi. Dikalangan masyarakat itu sendiri limbah juga diartikan demikian dimana benda ini merupakan material sisa baik itu yang terjadi secara alami maupun secara teknologi yang tidak lagi memiliki nilai. Pada dasarnya benda ini cinderung dianggap sebagai benda yang dapat mencemari lingkungan baik itu pencemaran lingkungan yang bersifat sementara ataupun pencemaran dalam waktu yang sangat lama. Hal ini dapat disebabkan oleh bermacam-macam faktor diantaranya adalah material dasar yang tergolong pada zat yang tidak dapat diuraikan oleh mikroorganisme sehingga benda tidak dapat hancur.

Kaca banyak digunakan di berbagai keperluan manusia. Hal ini menuntut bahan ini di produksi dalam jumlah yang sangat besar. Semakin besar jumlah produksinya akan berbanding lurus dengan produksi limbah yang dihasilkan, maka hal ini akan menimbulkan dampak pada kerusakan lingkungan dikarenakan kaca adalah material yang sifatnya tidak korosif. Cult atau Kaca bekas yang sudah tidak terpakai lagi merupakan limbah yang tidak akan terurai secara alami oleh zat organik. Maka diperlukan berbagai metode penanganan alternatif untuk mengolah limbah kaca dapat dikembalikan ke alam secara aman atau mengolahnya kembali menjadi produk yang bermanfaat.

Seni secara umum dapat dibedakan menjadi 2 mahzab besar yakni seni murni dan seni terapan. Seni murni adalah seni yang pada intinya adalah ungkapan persaan seniman melalui media seninya tanpa ada embel-embel apapun. Bertolak belakang dengan seni terapan. Seni terapan adalah karya seni yang khusus dibuat sebagai benda-benda terpakai (fungsional) untuk memperindah kebutuhan manusia. Meskipun kedua penggolongan seni tersebut secara esensi bermakna berbeda namun tetap ada kesamaan yakni sama-sama memerlukan skill dalam proses pembuatannya. 
Limbah kaca dapat diolah dalam kedua kategori seni tersebut namun yang membedakanya yakni seberapa jauh nilai fungsional yang melekat pada benda itu. Sebagai contoh; jika suatu material diolah menjadi benda terpakai seperti sepatu, pakaian, tas dan lain-lain maka benda tersebut dapat dikategorikan sebagai benda seni terapan dan begitu juga sebaliknya. Dalam hal ini penggunaan kreatifitas seni sebagai metode pengolahan kembali benda tak terpakai atau limbah merupakan upaya untuk mengurangi jumlah limbah tak korosif di lingkungan. Hal ini yang memunculkan ide pengolahan limbah menjadi karya seni yang bernilai.



Gambar 1. Proses pembentukan huruf kaligrafi dari material kaca

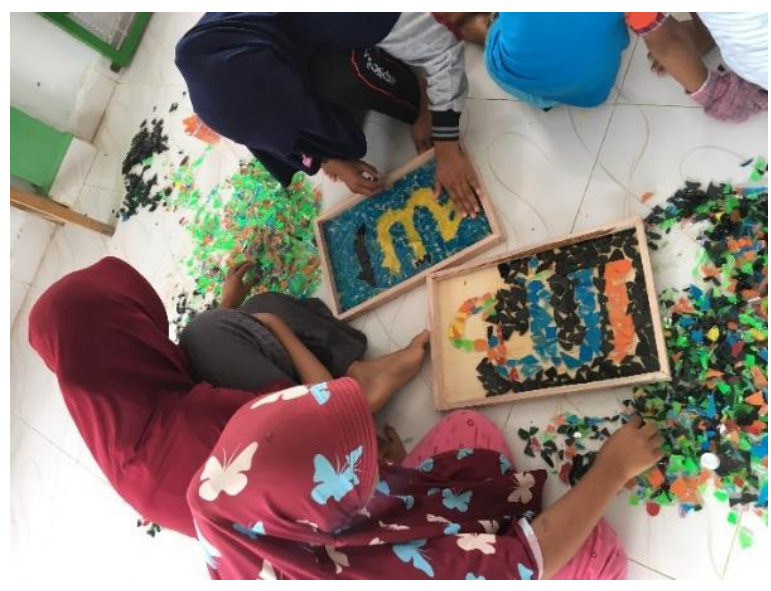

Gambar 2. Proses penyusunan kaca di atas media kayu

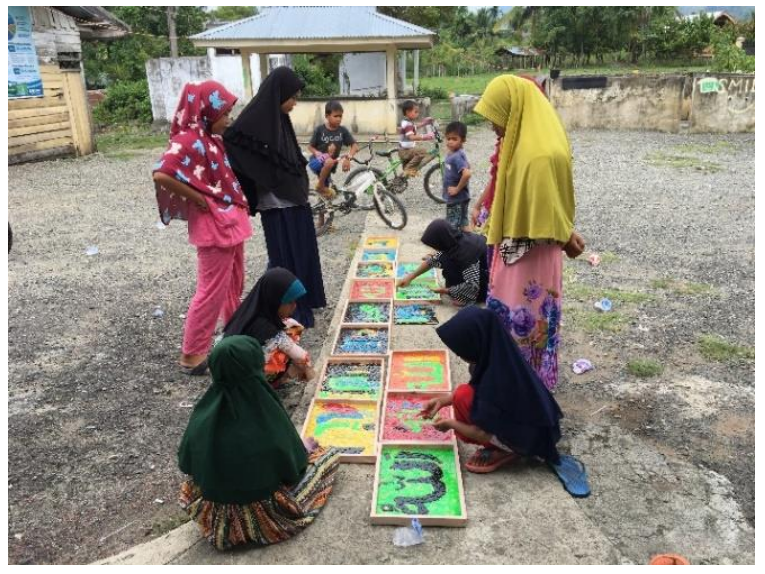

Gambar 3. Tahap finishing

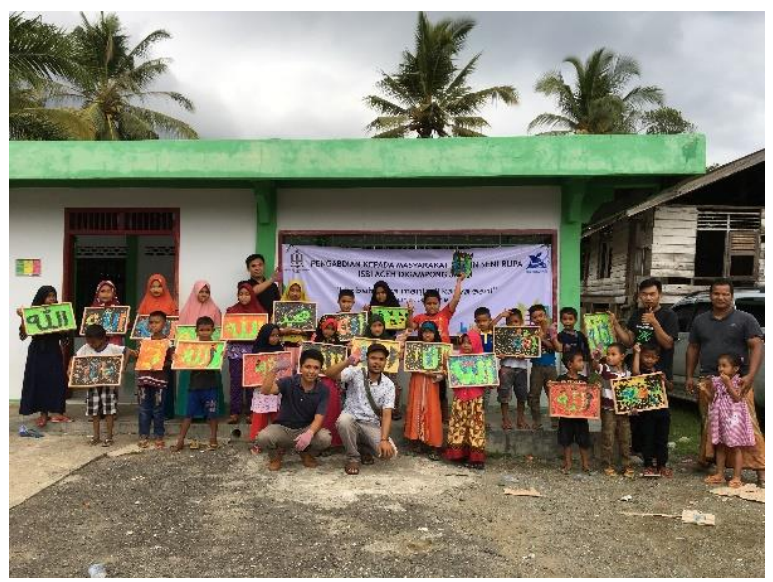

Gambar 4. Hasil akhir

\section{KESIMPULAN}

Aceh merupakan salah satu provinsi yang ada di Indonesia yang memiliki kultur keislaman yang sangat kuat. Budaya islam merupakan pandangan hidup masyarakat aceh yang memiliki nilai-nilai luhur yang patut untuk diperjuangkan. Begitu pula dengan seni, yang mana seni harusnya secara menyeluruh di atur oleh hukum islam. Hal ini ditandai oleh berlakunya hukum-hukum syariat yang kuat di tengah masyarakat. Dengan demikian islam juga turut menjadi budaya yang berkembang. Salah satu seni islam yakni kaligrafi. Kaligrafi itu sendiri merupakan seni menulis dengan merangkai huruf dengan penuh keindahan sehingga terlihat elok di pandang mata. Hal ini menimbulkan ide baru bahwa seni islam tidak hanya dapat dikembangkan melalui keindahan tulisan kaligrafi konvensional saja melainkan dapat di kreasikan kedalam bentuk yang beraneka ragam yang sesuai dengan syariat islam.

\section{DAFTAR PUSTAKA}

Djelantik, A.A.M. (1999) : Estetika Sebuah Pengantar. Masyarakat Seni Pertunjukan Indonesia 
George Kenneth M. 2012, MELUKIS ISLAM : Amal dan Etika Seni Islam Di Indonesia, Mizan.

Joshua Justin, 2015, Eksplorasi Limbah Kaca, eProsiding of Art \& Design, Vol. 2, No. 2

Mukhlas Khasani, 2013, Pemanfaatan Bubur Kertas Untuk Pembuatan KAligrafi Sebagai Upaya Pembinaan Kreativitas SAntri TPA AL-
Luqmaniyyah di Kelurahan Pandeyan Kecamatan Umbulharjo Yogyakarta, Skripsi.

Shidiq Abdurrahman, dkk, 2015, Pemanfaatan Limah KAca Sebagai Bahan Baku Pengembangan Produk. Jurnal Tingkat Sarjana Senirupa \& Design, Vol. 1, No. 1

Tabrani, Primadi, Prof. Dr. 2000, Proses Kreasi,

Apresiasi, Belajar, Penerbit ITB, Bandung. 